\title{
Peranan Metode Eurhythmics Terhadap Peningkatan Kreativitas Gerak
}

\author{
Oriana Tio Parahita Nainggolan ${ }^{1}$ \\ Jurusan Musik, Fakultas Seni Pertunjukan, Institut Seni Indonesia Yogyakarta
}

\begin{abstract}
ABSTRAK
Penelitian ini mengkaji peranan metode pembelajaran musik eurhythmics terhadap peningkatan kreativitas gerak anak usia 0,8 - 10,0 tahun. Kreativitas adalah kemampuan seseorang untuk membuat atau menciptakan sesuatu yang baru dari apa yang telah ada maupun yang belum pernah ada, yang secara operasional tercermin dari kelancaran, keluwesan, dan orisinalitas dalam berpikir, serta kemampuan untuk mengelaborasi. Kreativitas dapat dipelajari dan ditingkatkan. Salah satu cara dalam meningkatkan kreativitas adalah melalui pembelajaran musik. Penelitian ini menggunakan desain penelitian Randomized Group Pretest-Posttest, dimana pengukuran kreativitas gerak dilakukan pada saat sebelum dan sesudah dilakukan pembelajaran musik dengan menggunakan metode eurhythmics. Analisis data yang digunakan adalah T-test. Hasil penelitian ini menunjukkan bahwa metode eurhythmics memiliki peranan dalam peningkatan kreativitas gerak anak usia 0,8 - 10,0 tahun.
\end{abstract}

Kata kunci: kreativitas gerak; eurhythmics; musik

\begin{abstract}
The Role of Eurhythmics Methods towards the Improvement of Movement Creativity. This study examines the role of eurhythmics methods towards the improvement of movement creativity with children $0.8-10.0$ years old. Creativity is the ability to create or invent something new from what already exists and which has never existed, which is operationally reflected fluency, flexibility and originality in thinking, and the ability to elaborate. Creativity can be learned and improved. One way to increase creativity is through learning music. This study uses a randomized study design group pretest-posttest, where the movement creativity measurements before and after the music learning. The data analysis used T-test. The results of this study indicate that the method eurhythmics have a role in enhancing movement creativity with children $0.8-10.0$ years old.
\end{abstract}

Keywords: movement creativity; eurhythmics; music

\section{Pendahuluan}

Secara umum tujuan pendidikan adalah menyediakan lingkungan yang memungkinkan seluruh peserta didik untuk dapat mengembangkan bakat dan kemampuannya secara optimal, sehingga peserta didik dapat mewujudkan dirinya dan berfungsi sepenuhnya sesuai dengan kebutuhan pribadinya dan masyarakat. Hal ini sejalan dengan pendapat Rosmiati (2014) yang menyatakan bahwa melalui pendidikan, seluruh potensi yang ada pada seseorang akan dapat dikembangkan.

Pendidikan bertanggung jawab untuk memandu (mengidentifikasi dan membina) serta memupuk (mengembangkan dan meningkatkan) bakat dan kemampuan peserta didik. Dahulu masyarakat biasanya mengartikan "orang yang berbakat" adalah orang yang memiliki tingkat kecerdasan (IQ) yang tinggi. Namun, menurut $\mathrm{Mu}-$ nandar (1999) sekarang semakin disadari bahwa yang menentukan keberbakatan bukan hanya inteligensi (kecerdasan) melainkan juga kreativitas dan motivasi untuk berprestasi.

Hal yang menarik dari ketiga faktor yang menentukan keberbakatan adalah dimasukkannya elemen kreativitas. Selama ini kreativitas sering dianggap bukan hal yang penting dalam keberbakatan, karena yang dianggap penting dalam keberbakatan

Alamat korespondensi: Jurusan Musik, Fakultas Seni Pertunjukan ISI Yogyakarta. Jln. Parangtritis km.6,5. Sewon Yogyakarta. Tlp: (0274) 375380. E-mail: orianatioparahitangl@gmail.com 
adalah inteligensi. Munandar (1999) mengatakan bahwa kreativitas merupakan daya cipta yang memungkinkan munculnya penemuan-penemuan baru dalam bidang ilmu dan teknologi, serta dalam semua bidang usaha manusia lainnya.

Kreativitas ditemukan hampir dalam seluruh bidang ilmu dan teknologi. Menurut Munandar (1999) kreativitas adalah sebuah proses yang diwujudkan dalam kelancaran, fleksibilitas, dan orisinalitas dalam berpikir. Dalam uraiannya tentang pengertian kreativitas, ia menunjukkan ada tiga tekanan kemampuan, yaitu: 1) Kemampuan untuk membuat kombinasi baru berdasarkan data, informasi atau unsur-unsur yang ada; 2) Kemampuan menemukan banyak kemungkinan jawaban terhadap suatu masalah berdasarkan data yang ada (berpikir secara divergen); dan 3) Kemampuan yang secara operasional mencerminkan kelancaran, keluwesan dan orisinalitas dalam berpikir, serta kemampuan untuk mengelaborasi suatu gagasan.

Dalam penelitian ini, kreativitas yang akan diteliti adalah kreativitas gerak. Kreativitas gerak menjadi hal yang penting, karena bagi sebagian orang, gerakan menjadi sebuah hal yang dapat membantu untuk melahirkan ide-ide kreatif, dan tentunya hal ini tidak hanya berlaku bagi para penari saja, tapi juga bagi setiap orang, terutama bagi anak. Kreativitas gerak adalah kemampuan mental dari berbagai jenis keterampilan khas manusia yang dapat melahirkan pengungkapan yang unik, berbeda, orisinal, yang merupakan bahasa komunikasi yang luas dan variasi dari unsur-unsur yang sama sekali baru, indah, tepat sasaran dan tepat guna serta memiliki makna (Alma Hawkins, 2003).

Ada banyak cara yang dapat digunakan untuk meningkatkan kreativitas dalam gerak pada anak, salah satunya adalah melalui musik. Menurut Satiadarma dan Zahra (2004) Musik diyakini dapat meningkatkan kreativitas gerak anak karena dalam musik dan gerak memiliki kesamaan elemen yaitu ritme. Pada umumnya, anak-anak merupakan makhluk multiritmik. Sebagai makhluk multiritmik, anak-anak mudah memberi respon fisik terhadap ritme musik, bahkan responnya relatif spontan, dan anak-anak cenderung menggerakkan tubuh dan anggota tubuhnya. Aktivitas motorik ini merangsang pertumbuhan anak, khususnya pada awal masa perkembangan.

\section{Metode Eurhythmics}

Dalam pengajaran musik, dikenal sebuah metode yang dalam pengajarannya menggunakan elemen gerak. Metode ini disebut dengan naama metode Eurhythimc. Metode ini diciptakan oleh Emilie Jaques Dalcroze ketika menemukan bahwa kebanyakan dari siswanya mengalami kesulitan dalam memahami elemen-elemen musik yang diajarkan. Metode Eurhythmics mengajarkan musik melalui gerak, dengan tujuan agar dapat merasakan elemen-elemen musik yang diajarkan. Dalcroze menggunakan elemen gerak agar siswa dapat memahami elemen musik yang diajarkan.

Dalam metode Eurhythmics, pengajaran musik dilakukan dengan menggunakan tiga elemen, yaitu gerak tubuh, Solfege (kemampuan mendengar musik) dan improvisasi. Ketiga elemen ini merupakan sebuah kesatuan dalam mengajarkan musik. Ada empat dasar yang dijadikan Dalcroze sebagai landasan berpikirnya yaitu: 1) Metode eurhythmics menjadi dasar dari sebuah gerakan fisik, latihan pendengaran dan gambaran visual dari berbagai macam elemen-elemen musik; 2) Dengan menggabungkan elemen-elemen yang ada dalam metode eurhythmics yakni eurhythmics, solfege, dan improvisasi, serta kemampuan kreatif, mendasari kekuatan ekspresi siswa, lebih daripada sebuah kekuatan pemahaman secara intelektual saja; 3) Seluruh aspek musik menjadi sebuah pengalaman yang menarik karena dilakukan melalui gerakan; dan 4) Seluruh proses awal belajar melalui rasa. Maksudnya adalah dengan penggabungan gerak, solfege, dan improvisasi akan menjadi kekuatan dalam metode ini yang digunakan sebagai katalisator untuk belajar.

Eurhythmics berasal dari bahasa Yunani, dari akar kata eu dan rhytmos yang artinya good flow atau good movement. Sesuai dengan arti kata eurhythmics yang berarti gerakan yang baik, maka inti dari eurhythmics adalah reaksi spontan dan realisasi individu dalam bergerak untuk mengungkapkan perasaan musikal yang ada dalam 
diri setiap manusia. Aktivitas-aktivitas yang dapat dilakukan dalam bagian ini adalah: 1) Bernyanyi, menari, menggabungkan nyanyian dan tarian; 2) Memainkan alat musik; 3) Kondakting; 4) Menciptakan gerakan untuk mengekspresikan sebuah ide musikal; dan 5) Membuat gerakan dari elemen-elemen musik seperti ritme, melodi, bentuk musik. Gerakan yang digunakan dalam metode eurhythmics bukanlah gerakan yang digunakan dalam tari, gerakan yang digunakan adalah gerak alami manusia, seperti berjalan, berlari, melompat, bertepuk tangan, dan lainnya.

Solfege (kemampuan mendengar musik) merupakan salah satu kemampuan yang mendukung pengajaran musik dengan menggunakan metode Eurhythmics. Kemampuan ini menguatkan pendengaran dan interaksi fisik. Solfege diajarkan dalam dua cara yaitu melodic dictation (mendikte melodi) dan rhythm dictation (mendikte ritme), dengan menggunakan sistem membaca notasi fixeddo (do tetap yang artinya nada do atau nada pertama ada pada nada C). Dengan menggunakan sistem fixed-do, siswa dituntut untuk mampu mendegar dan mengingat pitch (tinggi rendah nada) yang sebenarnya.

Improvisasi merupakan bagian yang penting dari metode ini. Bagian ini merupakan kelanjutan dari latihan solfege dan eurhythmics. Ketika Dalcroze memperhatikan murid-muridnya pada saat merespon irama musik, ia menemukan siswasiswanya merespon musik tidak dengan satu cara saja (misalnya gerak tubuh saja), maka Dalcroze memberikan kesempatan dan pilihan kepada murid-muridnya untuk mengekspresikan perasaanperasaan musikal mereka melalui permainan alat musik, bernyanyi atau melalui gerakan. Mead (1994) mengatakan bahwa improvisasi merupakan bagian yang penting dalam metode eurhythmics

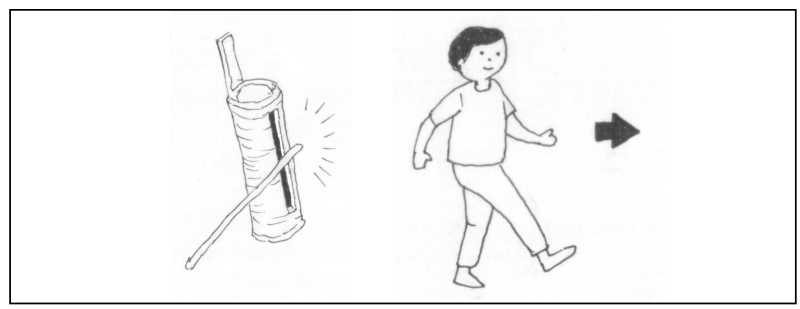

Gambar 1. Gerak berjalan berdasarkan bunyi kentongan bambu. (Sumber: Tio, 2015) karena: 1) Membantu siswa untuk menyatukan apa yang telah mereka pelajari menjadi sebuah bentuk pengalaman dalam mempelajari musik; 2) Sebagai sebuah sarana untuk menunjukkan apa yang telah dipelajari dan dipahami oleh siswa; 3) Memotivasi siswa untuk mengekspresikan ide-ide musikal dengan cara mereka masingmasing; 4) Menstimulasi kemampuan siswa untuk berkonsentrasi dalam mendengarkan musik; 5) Memperluas imajinasi siswa serta melatih pikiran musikal mereka; dan 6) Menghasilkan kepuasan hati siswa pada saat melakukan improvisasi.

Dalam penelitian ini, modul pembelajaran musik dirancang berdasarkan metode eurhythmics, dengan mengelaborasi elemen eurhythmics, solfege dan improvisasi. Salah satu modul pembelajaran yang akan dijadikan sebagai contoh elaborasi ketiga elemen ini adalah tentang konsep bunyi dan diam. Konsep bunyi yang digunakan adalah bunyi yang berasal dari instrumen kentongan bambu, triangel, dan castanets. Siswa dikenalkan pada bunyi yang berasal dari masing-masing instrumen ini. Setelah siswa mengenal masing-masing sumber bunyi, siswa harus merespon sumber bunyi ini dengan melakukan gerak seperti orang berjalan, satu sumber bunyi satu cara berjalan. Karena terdapat tiga sumber bunyi, maka siswa harus membuat tiga cara berjalan. Contohnya: bila siswa mendengar bunyi yang berasal dari kentongan bambu, siswa berjalan ke depan, bila siswa mendengar bunyi yang berasal dari triangel, siswa berjalan ke belakang, bila siswa mendegar bunyi yang berasal dari castanets, siswa berjalan ke samping kiri. Apabila siswa tidak mendengar bunyi dari ketiga instrumen ini, maka siswa harus tetap berdiri tegap. Bagian mendengar bunyi dan merespon bunyi dengan cara berjalan merupakan contoh dari penggunaan eurhythmics dan solfege.

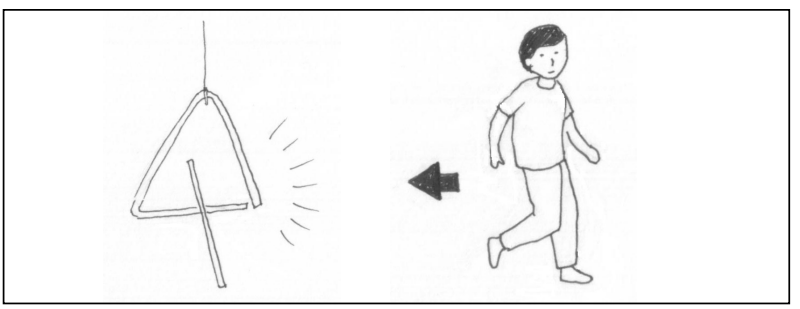

Gambar 2. Gerak berjalan berdasarkan bunyi triangle. (Sumber: Tio, 2015) 


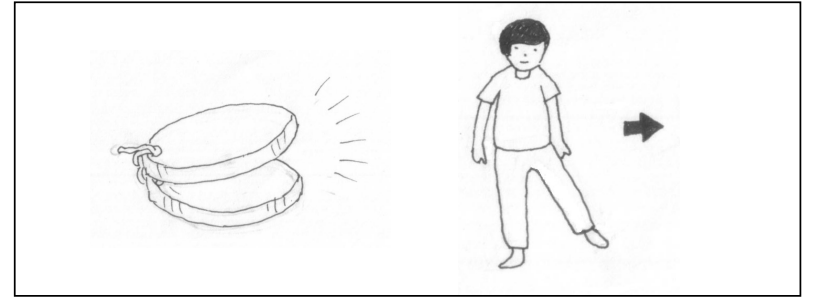

Gambar 3. Gerak berjalan berdasarkan bunyi castanets. (Sumber: Tio, 2015)

Elemen improvisasi pada modul ini dilakukan pada saat akhir dari pembelajaran ini, yaitu apabila siswa menguasai konsep bunyi dan diam ini, siswa diberi kesempatan untuk merespon bunyi yang berasal dari ketiga instrumen di atas dengan menggunakan cara berjalan yang mereka ciptakan sendiri. Pada bagian ini, siswa dituntut untuk menggunakan ide-ide kreatif mereka, sehingga respon gerak yang diberikan berbeda dari gerak yang sebelumnya.

\section{Kreatifitas Gerak}

Munandar (1999) menjelaskan bahwa kreativitas merupakan kemampuan seseorang untuk melahirkan sesuatu yang baru, baik berupa gagasan maupun karya nyata, baik dalam bentuk ciri-ciri aptitude maupun non aptitude. Aptitute meliputi: (1) kelancaran yaitu kemampuan untuk mengungkapkan ide-ide secara cepat di mana penekannya pada kuantitas dan bukan pada kualitas; (2) keluwesan yaitu kemampuan untuk memproduksi berbagai macam ide-ide yang bebas dari tekanan; (3) orisinalitas yaitu kemampuan untuk memproduksi ide-ide unik atau tidak biasa; (4) kemampuan mengelaborasi yaitu kemampuan mengembangkan, memperkaya, dan menemukan suatu gagasan. Kemampuan non aptitude meliputi rasa ingin tahu, senang bertanya, dan selalu ingin mengembangkan pengalaman baru), baik dalam karya baru maupun kombinasi dengan hal-hal yang telah ada, yang semuanya itu relatif berbeda dengan apa yang telah ada sebelumnya.

Kreativitas gerak merupakan kemampuan seseorang untuk membuat atau menciptakan sesuatu yang baru dari segala apa yang telah ada maupun yang belum pernah ada, yang secara operasional tercermin dari kelancaran, keluwesan dan orisinalitas dalam berpikir, serta kemampuan untuk mengelaborasi suatu gagasan dalam bentuk gerakan. Kreativitas subjek penelitian dinilai dengan menggunakan alat ukur kreativitas gerak yang diadaptasi dan dikembangkan oleh Melina Surya Dewi (2003) dari tes kreativitas verbal yang dibuat oleh Utami Munandar pada tahun 1977. Variabel kreativitas gerak diukur berdasarkan hasil penilaian yang dilakukan penilai (rater). Untuk setiap dimensi variabel yang diamati diberi skor sebagai berikut: 1) Baik Sekali (BS) mendapat skor 5; 2) Baik (B) mendapat skor 4; 3) Sedang (S) mendapat skor 3; 4) Cukup (C) mendapat skor 2; dan 5) Kurang (K) mendapat skor 1.

Dimensi variabel kreativitas gerak terdiri dari: 1) Kelancaran gerak; 2) Fleksibilitas; 3) Elaborasi; dan 4) Orisinalitas. Blue print instrumen kreativitas gerak dapat dilihat pada tabel 1 .

\section{Hasil Penelitian dan Pembahasan}

Pelaksanaan penelitian didahului oleh rangkaian tes untuk memenuhi persyaratan disain penelitian Randomized Group Pretest-Posttest. Penelitian ini dilakukan terhadap anak yang berusia 8.0 sampai 10.0 tahun. Subjek dalam penelitian ini adlaah 53 orang, yang terbagi dalam dua kelompok. Kelompok pertama terdiri dari 27 subjek, dan disebut sebagai kelompok eksperimen. Kelompok kedua terdiri dari 26 subjek, dan disebut sebagai kelompok kontrol. Kelompok eksperimen adalah kelompok yang mendapat perlakuan. Perlakuan yang dimaksud adalah pemberian pembelajaran musik dengan menggunakan metode eurhythmics. Sedangkan kelompok kontrol merupakan kelompok yang tidak mendapat pembelajaran musik dengan menggunakan metode eurhythmics.

Langkah pertama adalah menguji homogenitas subjek penelitian dengan menggunakan tes $C P M$ (Color Progressive Matrices). Setelah didapat homogenitas subjek, maka langkah berikutnya adalah menguji kemampuan kreativitas seluruh subjek, tes ini disebut sebagai pretest kreativitas gerak. Tes kemampuan kreativitas gerak dilakukan oleh 3 rater (penilai uji kreativitas). Setelah menguji kreativitas gerak, maka kelompok eksperimen mendapat pembelajaran musik dengan 


\begin{tabular}{|c|c|c|c|c|}
\hline Variabel & $\begin{array}{l}\text { Indikator } \\
\text { (Aspek yang } \\
\text { dinilai) }\end{array}$ & Diskriptor & Klasifikasi & $\begin{array}{l}\text { Waktu } \\
\text { (detik) }\end{array}$ \\
\hline \multirow{8}{*}{$\begin{array}{l}\text { Kreativitas } \\
\text { Gerak }\end{array}$} & 1. Kelancaran & 1. Peragaan berbagai pose & $\begin{array}{l}\text { 1. Membuat berbagai macam } \\
\text { pose anggota tubuh }\end{array}$ & 30 \\
\hline & & 2. Reorganisasi gerakan & $\begin{array}{l}\text { 2. Menginterpretasikan gerak } \\
\text { yang dibuat oleh instruktur } \\
\text { dan membuat kembali gerakan } \\
\text { tersebut dengan menggunakan } \\
\text { anggota tubuh yang lain }\end{array}$ & 30 \\
\hline & & 3. Membentuk rangkaian & $\begin{array}{l}\text { 3. Membuat gerakan yang terdi- } \\
\text { ri dari gerakan kepala, tangan, } \\
\text { dan kaki dalam posisi berdiri }\end{array}$ & 30 \\
\hline & & $\begin{array}{l}\text { 4. Membentuk rangkaian } \\
\text { gerak kepala, tangan, dan } \\
\text { kaki pada level rendah }\end{array}$ & $\begin{array}{l}\text { 4. Membuat gerakan yang terdi- } \\
\text { ri dari gerakan kepala, tangan, } \\
\text { dan kaki dengan posisi tubuh } \\
\text { rendah, misalnya jongkok, } \\
\text { duduk di lantai, berbaring, } \\
\text { dan lainnya }\end{array}$ & 30 \\
\hline & & 5. Susunan gerak bertema & $\begin{array}{l}\text { 5. Membuat gerakan bertema } \\
\text { dengan sifat yang berlawanan } \\
\text { yaitu buas-tidak buas, lucu-ti- } \\
\text { dak lucu, dan tenang-tidak } \\
\text { tenang }\end{array}$ & 30 \\
\hline & 2. Fleksibilitas & $\begin{array}{l}\text { Rangkaian gerakan dengan } \\
\text { properti yaitu koran dan } \\
\text { selendang }\end{array}$ & $\begin{array}{l}\text { Membuat gerakan dari properti } \\
\text { yang telah disediakan yaitu } \\
\text { koran dan selendang dengan } \\
\text { cara menggunakan benda- } \\
\text { benda tersebut secara tidak biasa, } \\
\text { contohnya untuk penggunaan } \\
\text { selendang tidak boleh diikat } \\
\text { dipinggang seperti pada penari } \\
\text { tradisional pada umumnya, } \\
\text { sedangkan untuk penggunaan } \\
\text { koran tidak boleh dipegang } \\
\text { seperti orang membaca koran. }\end{array}$ & 30 \\
\hline & 3. Elaborasi & $\begin{array}{l}\text { Peragaan rangkaian gerak } \\
\text { bertema dengan musik }\end{array}$ & $\begin{array}{l}\text { Membuat dan mengembangkan } \\
\text { gerak bertema pada tugas } 1.5 \\
\text { dengan iringan musik }\end{array}$ & 30 \\
\hline & 4. Orisinalitas & $\begin{array}{l}\text { Gerakan yang tidak biasa } \\
\text { (unik) }\end{array}$ & $\begin{array}{l}\text { Membuat berbagai macam gerak } \\
\text { yang lain dari pada biasanya }\end{array}$ & 30 \\
\hline
\end{tabular}

Tabel 1. Blueprint alat ukur kreativitas gerak 
menggunakan metode eurhythmics dengan jumlah tatap muka sebanyak delapan kali pengajaran. Akhir dari pertemuan ke-delapan, dilakukan tes kreativitas gerak kembali pada kedua kelompok subjek penelitian.

Hasil perhitungan skor tes kreativitas gerak sebelum (pretest) dan sesudah (posttest) dilakukan pengajaran musik dengan menggunakan metode eurhythmics, merupakan data untuk melihat peningkatan kreativitas gerak subjek penelitian. Sebelum melihat peningkatan kreativitas gerak subjek penelitian, hasil skor kreativitas gerak terlebih dahulu dilakukan uji normalitas data penelitian dengan menggunakan kolmogorov-smirnov. Uji normalitas bertujuan untuk mengurangi perbedaan persepsi diantara para rater dalam menilai kreativitas gerak subjek penelitian. Uji normalitas data ini akan membandingkan distribusi data yang akan diuji normalitasnya dengan distribusi data normal baku yang telah ditransformasikan dalam bentuk $z$-score yang diasumsikan normal. Pengujian dengan menggunakan Kolmogorov-

One-Sample Kolmogorov-Smirnov Test

\begin{tabular}{llrr}
\hline & & PreTest & $\begin{array}{r}\text { Post } \\
\text { Test }\end{array}$ \\
\hline $\mathrm{N}$ & & 27 & 27 \\
Normal Parameters ${ }^{\text {a,b }}$ & Mean & 33,74 & 36,41 \\
& Std. Deviation & 2,82 & 2,50 \\
Most Extreme & Absolute &, 137 &, 182 \\
Differences & Positive &, 101 &, 151 \\
& Negative &,- 137 &,- 182 \\
Kolmogorov-Smirnov Z &, 713 &, 948 \\
Asymp. Sig. (2-tailed) & &, 689 &, 330 \\
\hline a. Test distribution is Normal & & & \\
b. Calculated from data & & & \\
Tabel 2. Output Kolmogorov-Smirnov kelompok eksperimen
\end{tabular}

One-Sample Kolmogorov-Smirnov Test

\begin{tabular}{llrr}
\hline & & PreTest & $\begin{array}{r}\text { Post } \\
\text { Test }\end{array}$ \\
\hline N & & 26 & 26 \\
Normal Parameters ${ }^{\text {a,b }}$ & Mean & 31,38 & 31,27 \\
& Std. Deviation & 4,73 & 4,63 \\
Most Extreme & Absolute &, 121 &, 131 \\
Differences & Positive &, 117 &, 108 \\
& Negative &,- 121 &,- 131 \\
Kolmogorov-Smirnov Z &, 619 &, 666 \\
Asymp. Sig. (2-tailed) & &, 838 &, 767 \\
\hline a. Test distribution is Normal & & &
\end{tabular}

b. Calculated from data

Tabel 3. Output Kolmogorov-Smirnov kelompok kontrol
Smirnov menggunakan taraf signifikansi sebesar 0,05 . Taraf signifikansi adalah toleransi kesalahan pada saat pengambilan data penelitian. Apabila taraf signifikansi yang digunakan adalah 0, 05, maka ketepatan dalam mengukur data penelitian sebesar 95\%, dan toleransi kesalahan dalam mengambil data penelitian sebesar 5\%. Interpretasi hasil uji normalitas adalah jika nilai signifikansi KolmogorovSmirnov (z-score) lebih dari 0,05, maka distribusi data normal.

Dalam uji normalitas yang menggunakan Kolmogorov-Smirnov, data yang akan diuji normalitasnya terlihat pada item Asymp.Sig. (2-tailed), sedangkan data bakunya terlihat pada kolmogorov-Smirnov ( $Z$ ), atau Z-Score. Berikut normalitas data dari kelompok eksperimen dan kelompok kontrol setelah dilakukan pretest dan posttest kreativitas gerak.

Dari hasil analisis out put Kolmogorov-Smirnov diatas maka dapat dijelaskan bahwa seluruh data penelitian pada kelompok eksperimen dan kontrol terdistribusi secara normal. Hal ini dapat terlihat pada item $Z$-Score pada masing-masing kelompok tidak ada yang dibawah signifikansi $0,05(\mathrm{Z}>0,05)$, dan berarti bahwa data terdistribusi secara normal (Tabel 4).

Setelah diketahui bahwa skor kreativitas gerak subjek penelitian terdistribusi normal,

\begin{tabular}{lcccc}
\hline \multirow{2}{*}{ Variabel } & \multicolumn{3}{c}{ Kolmogorov- } \\
& Smirnov (z) & (2-tailed) & Keterangan \\
\hline \multirow{2}{*}{ Kel. Eksperimen Pre Test } &, 713 &, 689 & Data Normal \\
& Post Test &, 948 &, 330 & Data Normal \\
\multirow{2}{*}{ Kel.Kontrol } & Pre Test &, 619 &, 838 & Data Normal \\
& Post Test &, 666 &, 767 & Data Normal \\
\hline
\end{tabular}

Tabel 4. Hasil Analisis Kolmogorov-Smirnov

Paired SamplesTest

\begin{tabular}{|c|c|c|c|}
\hline & & & \begin{tabular}{|l} 
Pair 1 \\
Pre-Post \\
\end{tabular} \\
\hline \multirow[t]{5}{*}{ Paired Differences } & Mean & & $-2,67$ \\
\hline & Std. Deviation & & 2,24 \\
\hline & Std. Error Mean & &, 43 \\
\hline & 95\% Confidence & Lower & $-3,55$ \\
\hline & $\begin{array}{l}\text { Interval of the } \\
\text { Difference }\end{array}$ & Upper & -178 \\
\hline $\mathrm{t}$ & & & $-6,197$ \\
\hline df & & & 26 \\
\hline Sig. (2-tailed) & & &, 000 \\
\hline
\end{tabular}

Tabel 5. Output Uji T kelompok eksperimen 
kemudian dilakukan uji $t$ (t-test). Pengujian ini dilakukan untuk mengetahui perbedaan skor tes antara sebelum dan sesudah perlakuan pada subjek penelitian. Uji $t$ dilakukan dengan menggunakan tingkat signifikansi $P<0,05$, sehingga kriteria pengujian yang digunakan adalah jika nilai probabilitas (nilai p-value pada kolom sig.(2-tailed)) kurang dari 0,05 maka terdapat perbedaan kreativitas gerak di antara subjek penelitian dalam kelompok eksperimen dan kelompok kontrol, dan hal ini menunjukkan bahwa terdapat peningkatan kreativitas gerak (Tabel 5 dan Tabel 6).

Berdasarkan out put hasil uji tyang dilakukan, maka dapat ditarik kesimpulan, yaitu nilai statistik $t$ ( $t$ hitung) untuk subjek penelitian kelompok eksperimen diperoleh sebesar 6,197 dengan nilai p-value sebesar 0,000 dan tingkat signifikansi sebesar $\mathrm{p}<0,05$. Sesuai dengan kriteria pengujian uji $t$ di atas dapat disimpulkan bahwa nilai $p$-value lebih kecil daripada tingkat signifikansi $(0,000$ $<0,05)$, sehingga dapat disimpulkan terdapat perbedaan hasil antara pretest dan posttest kreativitas gerak kelompok eksperimen.

Selain dari hasil uji $t$, peningkatan skor kreativitas gerak dapat dilihat dari skor uji kreativitas gerak pada kedua kelompok penelitian seperti yang tertera pada grafik (Gambar 4). Skor tes kreativitas gerak kelompok eksperimen pada saat pretest adalah 33,74 dan meningkat secara signifikan pada posttest yaitu sebesar 36,41. Sedangkan skor uji kreativitas kelompok kontrol, terlihat tidak ada perubahan, bahkan cenderung menurun. Skor uji kreativitas gerak kelompok kontrol pada pretest sebesar 31, 38 dan pada posttest sebesar 31, 27.

\section{Paired SamplesTest}

\begin{tabular}{|c|c|c|c|}
\hline & & & $\begin{array}{l}\text { Pair } 1 \\
\text { Pre-Post }\end{array}$ \\
\hline \multirow[t]{6}{*}{ Paired Differences } & Mean & &, 12 \\
\hline & Std. Deviation & & ,33 \\
\hline & Std. Error Mean & & 6,39 \\
\hline & 95\% Confidence & Lower & $-1,62$ \\
\hline & Interval of the & Upper & ,25 \\
\hline & Difference & & \\
\hline \multicolumn{2}{|l|}{$\mathrm{t}$} & & 1,806 \\
\hline \multicolumn{2}{|l|}{$\mathrm{df}$} & & 25 \\
\hline \multicolumn{2}{|l|}{ Sig. (2-tailed) } & & ,000 \\
\hline
\end{tabular}

Tabel 6. Output Uji T kelompok kontrol

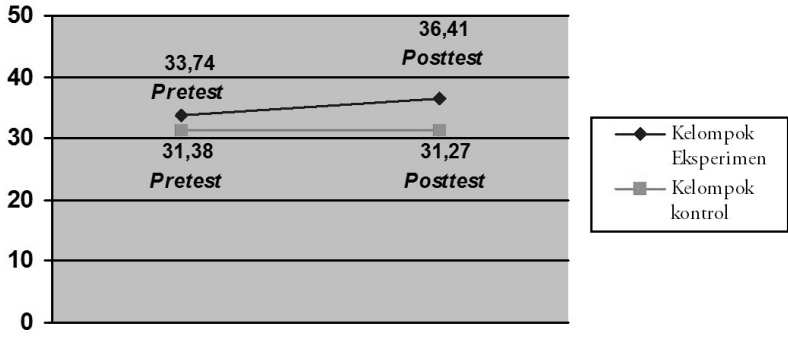

Gambar 4. Skor uji kreativitas gerak

Berdasarkan data-data yang telah disajikan di atas, maka dapat dilihat bahwa pelatihan eurhythmics memiliki peran dalam peningkatan kreativitas gerak. Dengan kata lain dapat disimpulkan bahwa melalui musik, kreativitas gerak seorang dapat ditingkatkan. Seperti yang dikutip oleh Fitriani (2014), bahwa musik memiliki dimensi kreatif dan memiliki bagian yang identik dengan proses kreatif secara umum. Maka peningkatan kreativitas gerak dalam penelitian ini merupakan manfaat dari pembelajaran musik yang telah dilakukan.

Hasil penelitian ini memperkuat teori yang dinyatakan oleh Wood (1982) bahwa musik dapat menstimulasi dan meningkatkan kreativitas gerak anak. Dengan meningkatkan kreativitas gerak anak, maka diharapkan anak dapat mengekspresikan ekspresi musikalnya. Menurut Rozmajzl dan Boyer (2006), gerak merupakan salah satu yang alami untuk menunjukkan ekspresi musikal. Hal ini dapat dilihat pada anak-anak, ketika mereka mendengarkan musik, mereka dapat mengekspresikan ekspresi musikalnya dengan gerakan seperti mengangguk-anggukan kepalanya, bertepuk tangan, menari dan lainnya.

\section{Penutup}

Musik dan gerak merupakan dua hal penting dalam pembelajaran musik. Gerak dapat membantu siswa dalam memahami elemen-elemen musik, sehingga siswa dapat memahami dan menerjemahkan elemen musik melalui gerak. Selain itu, melalui metode pengajaran musik eurhythmics, kreativitas gerak siswa dapat ditingkatkan. Peningkatan kreativitas gerak menunjukkan bahwa pembelajaran musik memberikan manfaat yang besar bagi perkembangan kreativitas secara umum ataupun kreativitas gerak secara khusus. 
Penelitian ini juga membuktikan bahwa musik memiliki dimensi kreatif yang dapat digunakan untuk pengembangan diri seseorang, memberikan stimulan untuk berpikir kritis, serta dapat digunakan sebagai salah satu bentuk ekspresi.

\section{Kepustakaan}

Dewi, S. M. 2003. "Peranan Gerak Tari Kreatif Siswa Dan Minat Tari Kreatif Siswa Terhadap Keberhasilan Belajar Menari Kreatif Siswa SLTP St. Theresia Jakarta”. [Tesis]. Jakarta: Universitas Indonesia.

Fitriani, Y. (2015). Model Pembelajaran Seni Musik melalui Lesson Study: Studi Kasus di SDN Jawilan, Serang. RESITAL : JURNAL SENI PERTUNJUKAN, 15(2), 126-138. doi:http:// dx.doi.org/10.24821/resital.v15i2.847

Hawkin, M. A. 2003. Mencipta Lewat Tari. (Diterjemahkan oleh: Y. Sumandiyo Hadi). Yogyakarta: Manthili.
Mead, H. V. 1994. Eurhythmics In Today's Music Classroom. New York: Schott.

Munandar, Utami. 1999. Kreativitas dan Keberbakatan, Strategi Mewujudkan Potensi Kreatif dan bakat. Jakarta: PT. Gramedia Pustaka Utama.

Rosmiati, A. (2014). Teknik Stimulasi dalam Pendidikan Karakter Anak Usia Dini melalui Lirik Lagu Dolanan. RESITAL : JURNAL SENI PERTUNJUKAN, 15(1), 71-82. doi:http://dx.doi.org/10.24821/resital. v15i1.801

Rozmajzl, M. dan Boyer, R. 2006. Music Fundamentals, Methods, and Materials For the Elementary Classroom Teacher ( $4^{\text {th }} \mathrm{ed}$ ). United States: Pearson Education.

Satiadarma, P. M. dan Zahra, P. R. 2004. Cerdas Dengan Musik. Jakarta: Puspa Sehat.

Wood, D. 1982. Move, Sing, Listen, Play Preparing The young Child For Music. Toronto: Thompson Music. 